\title{
Visualizing the Middle Passage: The Brooks and the Reality of Crowding in the Transatlantic Slave Trade
}

In January 1789, the Society for Effecting the Abolition of the Slave Trade (SEAST) published their famous diagram of the Liverpool slave ship Brooks (Figure 1). Emerging from measurements taken by Parliament, the scale model included 470 men, women and children, crowded together below the Brooks' decks. ${ }^{1}$ The Brooks diagram remains one of the most recognizable images in the history of print culture. Copied endlessly in books, magazines, museum halls, art exhibits, television shows, and even t-shirts, the Brooks diagram remains, as Marcus Wood wrote, "the most famous, widely-reproduced, and widely-adapted image representing slave conditions on the middle passage ever made." ${ }^{2}$ In this article, we argue, though, that the Brooks diagram's depiction of "ship crowding" on the Middle Passage is deeply flawed. The diagram does not capture the degree to which enslaved people were crowded on the Brooks itself, nor the majority of other British slaving vessels sailing prior to the passage of regulatory acts in 1789. In showing a single British vessel in the late eighteenth century, the Brooks diagram also does not depict the enormous variety in the ways that enslaved Africans were forcibly transported over the slave trade's nearly four-century history. The slave experience on transatlantic voyages before 1700 and after 1807 differed sharply from each other. And the experience in both eras were quite different from the British dominated trade of the late eighteenth century. We argue, therefore, that historians should certainly use the Brooks diagram to explain the abolitionist campaign's

\footnotetext{
${ }^{1}$ For the Brooks diagram's history, see, James Walvin, Black Ivory: A History of British Slavery (London, 1992), 4647; Marcus Wood, "Imaging the Unspeakable and Speaking the Unimaginable: The 'Description' of the Slave Ship Brookes and the Visual Interpretation of the Middle Passage," Lumen, XVI (1997): 211-45; Marcus Rediker, The Slave Ship: A Human History (London, 2007), 308-42.

${ }^{2}$ For the modern prominence of the Brooks plan, see, Marcus Wood, Blind Memory: Visual Representations of Slavery in England and America (New York, 2000), 19-77; Jacqueline Francis, "The Brooks Slave Ship Icon: A 'Universal Symbol'?," Slavery \& Abolition, XXX (2009), 327-38; Celeste-Marie Bernier, “The Slave Ship Imprint': Representing the Body, Memory, and History in Contemporary African American and Black British Painting, Photography, and Installation Art," Callaloo, XXXVII (2014): 990-1022. Marcus Wood, The Horrible Gift of Freedom: Atlantic Slavery and the Representation of Emancipation (Athens, GA, 2010), 267 ("the most"), 197-353.
} 
successful use of visual propaganda but not as an image that captures the African experience of the Middle Passage beyond the period of Britain's regulated slave trade, circa 1789 to $1808 .^{3}$

We illuminate these issues using other pictorial representations of ship crowding, which we interpret using quantitative data and the testimony of slave traders. We begin by exploring the Brooks diagram's production and demonstrate that its abolitionist authors never intended it to accurately represent ship crowding on the Middle Passage prior to 1789, when Parliament began regulating Britain's slave trade. The second and third sections of this paper explore several images that more accurately depict shipboard conditions in the transatlantic slave trade and how these conditions changed over time and space. We first examine the illustration of the French slave ship Marie-Séraphique which carried 307 enslaved people in 1769/70 — an image that was only unearthed in 2005. Unlike the abolitionists' schematic of the Brooks, two officers serving aboard the Marie-Séraphique accurately drew the vessel from life, including the crowding of the slaves. In the third section, we discuss shipping practices in the trade's early history, and then draw on three nineteenth century illustrations of slave ships to show the variety in the ways that Africans were forcibly transported in the trade's illegal era, post 1807 . We conclude by exploring digital technologies that might provide new ways of visualizing the Middle Passage that do not rely solely on problematic contemporary images such as the Brooks.

When the SEAST launched their campaign in May 1787, they strategically focused their attention on the crowding of enslaved Africans on the Middle Passage, a wedge issue that could

\footnotetext{
3 Thomas Clarkson, The History of the Rise, Progress, and Accomplishment of the Abolition of the African SlaveTrade, by the British Parliament (London, 1808) II, 111. Voyages: The Trans-Atlantic Slave Trade Database (hereafter TSTD), www.slavevoyages.org, contains no less than seventy-four types of ship, mainly different rigs. The five most common (bergantim, curveta, schooner, brig and ship) account for close to two-fifths of our sample of 23,500 records, but within these rigs, there was a wide variation in the size of the vessel.
} 
be both quantified with data and brought to life by witness testimony. It appeared "obvious" to the SEAST in March 1788 that they should, Clarkson continued, "select someone [sic] ship which had been engaged in the Slave Trade," draw a plan of the vessel "with her real dimensions" and then depict enslaved people trapped aboard. Because they could not board and draw slave ships from life, the SEAST relied on measurements of several Liverpool vessels that naval Captain Parry had taken in June 1788 at Parliament's behest. Parry took forty-three separate measurements of the nine vessels that had the barriers still in place that demarcated the "rooms" (as Parry labeled them in his report) where the Africans had been imprisoned between decks. Parliament tabulated Parry's data and made it available to both abolitionists and slave traders for use in the subsequent debates. "At the top of [Parry's] list," Clarkson wrote, "stood the ship Brookes" which the SEAST selected as the subject of their diagram thinking "it less objectionable to take the first [vessel] that came, than any other."

Registers of Liverpool shipping, which detail the dimensions of 606 slaving vessels conducting 2,083 voyages between 1782 and 1807, show that the Brooks was unusually large. The median slaving vessel measured 86' long and 24' wide, with a between deck height of 5'1'. The Brooks, by contrast, had a deck height of 5'6" inches and measured 99'8' in length, by 26'7'. Given her large size, the Brooks had carried more than double the average 259 people embarked

\footnotetext{
${ }^{4}$ Clarkson, History, II, 111; "Minutes of the Society for Effecting the Abolition of the Slave Trade," March 2, 22, 1788, British Library, Add Mss. 21253. On a typical merchant vessel, the between decks area was a low-ceilinged space with cabins and storage rooms. On a slave ship, carpenters knocked down the cabins and storerooms, and then erected horizontal "partitions" or "bulkheads" to create three separate "rooms:" the women's room, which ran from the mizzen mast to the mainmast; followed by the boys' room; and then the men's room, which terminated at the fore of the ship. Carpenters built the bulkheads out of four-inch-thick wooden boards, which were either a lattice work (like a prison gate), or solid, and each partition had a door with a lock. See, Testimony of James Jones in Sheila Lambert ed., House of Commons Sessional Papers of the Eighteenth Century (Wilmington DE, 1975), LXVIII, 3944. This was the division that Parry described in his report, and the nomenclature used by the abolitionists to describe the Brooks itself. For Parry's measurements, see, "DIMENSIONS of the following Ships in the Port of Liverpool, employed in the African Slave Trade," in Lambert ed., HCSP, LXVIII, 6. The partitions below deck should not be confused with the "barricado," a wooden wall that divided the above deck space at the main mast.
} 
by British vessels before 1788 on her four previous voyages. The selection of the Brooks may have forestalled accusations of bias, but it meant that the abolitionists' diagram showed an unusually large vessel with an unusually large number of African prisoners. Only the Brooks' ship rigging and configuration of barriers and walls to create temporary prisons for men, women, and boy slaves, reflected the typical British slaver. ${ }^{5}$

The SEAST did not want to depict a typical slave ship, however, because the diagram was produced to serve the campaign's specific aims of combatting Parliament's attempts to regulate, rather than abolish, the trade. In May 1788, Parliament had passed Sir William Dolben's, which limited the number of Africans that British slave ships could carry according to their tonnage. The SEAST now had to produce a diagram that would convince the public of the "inhumanity" of a regulated slave trade. To achieve these ends, the SEAST designed the diagram to show, as Clarkson explained, "how many persons" could be hypothetically "stowed" in the Brooks if they were allotted precisely their height and breadth, enough room that they could lie on their backs "without trespassing upon the room allotted to the rest." An unknown artist working for the Plymouth committee of the SEAST took Parry's measurements in November 1788 and rendered them into the shape of the vessel using "crude rule of thumb proportions," as Wood describes. The

\footnotetext{
${ }^{5}$ The names Brooks and Brookes were used interchangeably. For consistency, we use Brooks throughout this piece. For the selection of the Brooks, see, Clarkson, History, II, 112 ("At the"). Of the eight other vessels in Parry's report, three were larger, and five were smaller. The Brooks depicted by the abolitionists was the second vessel to bear the name. The first was built in 1772 and made two slaving voyages in 1775 and 1777. See, http://slavevoyages.org/voyages/a9VYxFHS. For the voyages of the second Brooks see, http://slavevoyages.org/voyages/aA02Tkz2. Prior to 1786, British official records included almost no information on the size of a vessel besides its tonnage, a figure that was manipulated by ship owners to save on customs fees. In 1786, Parliament passed the Shipping and Navigation Act, which mandated that ships had to be measured by an independent surveyor to calculate tonnage. Although these records are lost for Bristol and London they are complete for Liverpool's entire fleet of merchant vessels sailing between 1786 and 1808, including its slaving vessels. As maritime historian R.C. Jarvis points out, the shipping records of Liverpool "are the most perfect" of any in Britain (R.C. Jarvis, "Liverpool Statutory Registers of British Merchant Ships," Transactions of the Historic Society of Lancashire \& Cheshire, CV (1953), 107-22). The registers are held at the Merseyside Maritime Museum (C/EX/L/4). We entered them into a database, which we cross-referenced with the TSTD. The registers cover ninety-five percent of Liverpool slaving voyages between 1787 and 1808, and forty-three percent of voyages c.1782-1786. The coverage for the latter period is sparse because we could only trace ships that were registered before and after 1786.
} 
resulting sketch is a basic deck plan — really an outline — within which the artist drew 295 captives.

The London committee took the Plymouth sketch in early 1789 and improved its accuracy by using Parry's exact measurements and adding masts and "platforms" around the sides of the vessel, upon which enslaved people would have slept during the voyage. The London version lacked ropes, sails, toilets, gratings, doors between rooms, and was drawn in two dimensions, with separate figures to show the view of the vessel in cross-section. After drawing the captives, the SEAST discovered that the Brooks could hold 470 Africans (190 men, 183 women, 70 boys, 27 women). As Clarkson sardonically wrote, viewers of the diagram saw "the advantages of Sir William Dolben's bill" because "many, on looking at the plate, considered the regulation itself as perfect barbarism." But the Brooks had never carried that number of Africans on any of its previous voyages: over four voyages, it embarked 650 (1782), 619 (1784), 740 (1785), and 609 (1787) people. The diagram thus showed the number of slaves that the Brooks was permitted to carry after the passage of Dolben's Act, not the actual number of slaves carried on any of her previous voyages. $^{6}$

The images of the slaves themselves are simplified precisely because the SEAST wanted to calculate how many identical people would fit into an outline of the vessel. The artist drew men, women, boys, and girls but distinguished them only by altering the heights of each group of people; by adding breasts to the females; and shackles to the men's ankles and wrists. Within each age and

\footnotetext{
${ }^{6}$ For the production of the Brooks diagram, see, Wood, Blind Memory, 26. For the Plymouth diagram, see, Plan of an African Ship's Lower Deck with Negroes in the proportion of only One to a Ton (Plymouth, 1789). For the London version, see, Description of a Slave Ship (London, 1789). Unless otherwise specified, this article refers to the London version of the diagram. According to Clarkson, enslaved men were depicted in spaces measuring 6" by 16"; women, 5' by 16"; boys, 5' by 14"; and girls, 4'6" by 12". See, Clarkson, History, II, 113, 111 ("the advantages"). Dolben's Act specified that British slave ships could carry five slaves for every three tons, up to 201 tons, and then one slave for every subsequent ton. The 320-ton Brooks could consequently carry 454 slaves by law: (201/3)/5+ (320-201) = 454. See, "An Act to regulate, for a limited Time, the shipping and carrying Slaves in British Vessels from the Coast of Africa," 28 Geo III, c.54. Some versions of the diagram explicitly showed the vessel under Dolben's Act by depicting 451 slaves. See, Stowage of the British Slave Ship 'Brookes' Under the Regulated Slave Trade Act of 1788 (London[?], c.1789).
} 
gender group (that is to say, men, women, boys, and girls), the figures are identical in height; wear matching loin cloths; and all have the same appearance. Enslaved people would, of course, have differed markedly from the figurines depicted in the diagram. While slave traders sought to purchase captives of a similar height and age, the realities of the trade meant that captives of the same gender and age group ranged in height by as much as a foot; had differing builds; varying hair styles; and were entirely naked. Moreover, none of the captives in the image appear to be sickly or maimed, as many captives would have become on the Middle Passage. The Brooks diagram bore only a passing resemblance to the vessel itself: neither the Plymouth nor London artists saw her, let alone her captives. The diagram is a pictorial representation of a table of measurements and human figurines - an acceptable methodology for drawing a schematic of a vessel, but a flawed one for showing an actual slave ship.

Data from the Liverpool registers confirms that the diagram fails to accurately capture ship crowding on British vessels prior to the passage of Dolben's Act in 1788 (for our method of calculating crowding, see Appendix 1). The Brooks diagram showed slave decks measuring, according to Parry's report, 3,349' square within which 470 captives were imprisoned, providing each person an average 7'2" square. By comparison, the median degree of crowding on 251 voyages before 1788 was 6'4" square; on only sixty-eight ( 27 percent) of those voyages were the captives less crowded than the diagram showed. On 114 of the 251 voyages ( 45 percent), captives were crammed into spaces measuring less than 6' square per person - "tight packing" in the grim parlance of the trade. These 114 included all four of the Brooks' voyages. Median crowding on 895 voyages between 1789 and 1799 was 7'4" square, almost exactly the conditions depicted in the diagram. Between 1800, when Parliament passed new regulations limiting the number of slaves British ships could carry according to their dimensions rather than tonnage, and the trade's 
abolition in 1808 , space per captive increased to 9'5" square. The diagram thus depicts how 650,000 captives were transported aboard British vessels after 1788 - the era of the regulated slave trade. But, it is only revealing of the experiences of a small fraction of the two million Africans transported in the unregulated era. ${ }^{7}$

The SEAST wrote a lengthy description beneath the diagram, because they knew that that the schematic "Plans and Sections" of the Brooks alone "would appear rather a fiction, than a real representation of a slave ship." The SEAST admitted that the Brooks had transported 609 people on her previous 1786/7 voyage, whereas their own diagram showed 470 captives. On that voyage, the SEAST wrote, "the room allowed them, instead of being 16 inches as in the plan, was in reality only 10 inches." "The men," it added, "were placed, as is usual, in full ships, on their sides, or on each other." The text continued by describing the miseries that the Africans suffered in such crowded conditions: the "excessive heat" below deck, the "fluxes and fevers" that broke out, and suffocation when the port-holes had to be closed in bad weather. Modern users of the Brooks diagram, who typically display the diagram without this accompanying text, are thus utilizing an image that even its creators knew to be a deeply flawed visualization of the Middle Passage. The SEAST's artist had not seen the Brooks, nor boarded a slave ship. Neither does the diagram depict the numbers of slaves that had been imprisoned on the Brooks on any of its voyages, nor the degree to which they were crowded together. But the SEAST should not be blamed for these numerous faults. They intended the Brooks diagram as a tool that would convince the public that a regulated

\footnotetext{
${ }^{7}$ Parliament used the horizontal deck area to calculate crowding when it regulated the slave trade. In 1799, Parliament passed an act that limited the number of slaves a vessel could carry by dividing the horizontal area of its lower deck by eight. The area of the deck was calculated using by multiplying together "the extreme Length and Breadth, in Feet and Inches, of the Lower Deck of the said Vessel" See, "An Act for better regulating the Manner of carrying Slaves, in British Vessels, from the Coast of Africa, 1799," Georgii III. Cap. LXXX.
} 
slave trade was "barbarism" and they freely acknowledged the limitations of their image as a means of depicting the realities of the Middle Passage. ${ }^{8}$

The Brooks diagram has been used so extensively, despite its evident flaws, because there are few other contemporary images that depict fully loaded slave ships during the trade's legal era, barring numerous side-on-views of vessels standing at anchor. In 2005, though, a remarkable image of the Nantes ship Marie-Séraphique emerged. It shows 307 enslaved people (189 men; 60 women; 49 boys; and 9 girls) imprisoned in the vessel on her 1769/70 Middle Passage from Loango to Saint Domingue (Figure 2). The drawing forms part of a larger painting that depicts the MarieSéraphique's lower hold, upper hold, slave deck, and top-deck in cross-section; the vessel anchored at Loango (Figure 3); and tables detailing the voyage's profits. The painting is even more extraordinary because it matches another image, discovered in 1893, which depicts the MarieSéraphique in Saint Domingue during her 1772/3 voyage - the only extant picture of an American slave sale in the legal era of the transatlantic slave trade. A close inspection of the 2005 image reveals it to be the most accurate contemporary depiction of ship board conditions in the transatlantic slave trade during the late eighteenth century- the era of the Brooks. ${ }^{9}$ [Insert Figure 2 here]

\footnotetext{
${ }^{8}$ Description of a Slave Ship] (London, 1789). Testimony of Thomas Trotter in Lambert ed., HCSP, LXXIII, 83-4.

${ }^{9}$ For an excellent recent analysis of images of slave ships on ceramics, all of them taken side-on, see, Jane Webster, "'Success to the Dobson': commemorative artefacts depicting $18^{\text {th }}$-century British slave ships," Post-Medieval Archaelogy (2015) XLIX: 72-98. See also the Nicholas Pocock's sketches of the Bristol slave ships Southwell Frigate, Blanchford Frigate, and Jason Privateer, in the Bristol Record Office, UK. For the Marie-Séraphique's voyages, see, http://slavevoyages.org/voyages/odStmxUW. The 2005 image shows ID 30910, the 1893 painting ID 30968. The two images of the Marie-Séraphique are complemented by a sailor's shaving bowl, on which there is a further depiction of the vessel. Bertrand Guillet suggests that the image of the slave sale has been reproduced in almost one hundred different volumes, most of them in French. The 2005 image has yet to be utilized to any extent by historians of the slave trade in France or the Anglophone world. The images of the Marie-Séraphique hang in the Musée d'Histoire de Nantes, where Guillet is a curator. See, Bertrand Guillet, La Marie-Séraphique: Navire Négrier (Nantes, 2010).
} 
The Marie-Séraphique better represents the generality of British and French slave ships sailing in the second half of the eighteenth century than the large Brooks. She was built in Nantes specifically for the slave trade and launched in October 1764, originally under the name Dannecourt. While most slaving vessels were likely not built for the trade, the lay out of the MarieSéraphique was unremarkable, as she had two decks, a forecastle and quarter-deck, all features that could be found on eighteenth-century slavers, including the Brooks. Unlike the three-masted, ship-rigged Brooks, the Marie-Séraphique was snow rigged, meaning that she had only two masts, an unusual configuration that saved costs and increased speed. She measured $1,637^{\prime}$ 'square (67' by $\left.24^{\prime} 5^{\prime \prime}\right)$ when measured as a crude rectangle, making her just twenty-percent smaller than the typical Liverpool slave ship sailing in the period 1782-1808 (2,064' square), and forty-percent smaller than the massive Brooks (2,650' square). With an average of 357 people embarked on the Marie-Séraphique during her six voyages to Africa, she carried more than the 267 usually embarked on British vessels in the eighteenth century, but close to the 325 carried off by the typical French slaver. By comparison, the Brooks always carried more than double the average of British vessels. The Marie-Séraphique was slightly smaller than many contemporary slaving vessels and had a peculiar configuration of masts and sails, but she was otherwise representative of French slave ships sailing in the second half of the eighteenth century. She was also more typical of an eighteenth-century British slaving vessel than the Brooks. ${ }^{10}$

\footnotetext{
${ }^{10}$ Dannecourt undertook one slaving voyage (ID 30806) before her owners sold her, in June 1769, to Jacques Gruel, a merchant who re-named the vessel after his wife Marie-Séraphique. Gruel had previously re-named two other ships after his mother-in-law, Marie-Gabrielle (ID 30884), and his wife's family, Chavingy (a non-slaver). After dispatching the Marie-Séraphique on four slaving voyages to Angola, Gruel sold her to a group of Nantes merchants in 1776, who renamed her Sartine and outfitted her for a sixth and final slaving voyage (ID 31051). See, Guillet, Marie-Seraphique, 31-38. Information on the rig of French slaving vessels is not available in the TSTD. Of 7,597 British slaving voyages between 1701 and 1808, just 1,244 were snow ("snauw") rigged. Most (4,225) were ship rigged, like the Brooks. See, http://slavevoyages.org/voyages/guIxHdwP. Systematic data on the dimensions of French and British slave ships sailing before 1782 are not available because ship owners were not required to have their vessels measured to assess tonnage. For the dimensions of Liverpool slave ships in the period see note 7. For the average number of enslaved
} 
Two slave ship officers serving aboard the Marie-Séraphique painted her, apparently with much artistic ability. While the 1770 diagram of the slave deck is anonymous, the painting of the Marie-Séraphique's 1773 Saint Domingue slave sale is signed by Jean-Rene L'Hermite, who served as second lieutenant (equivalent to second mate) on the voyage. By 1773, L'Hermite had worked his way through the ranks on four other slaving voyages, including the Marie-Séraphique's 1769/70 and 1770/71 expeditions, and so he likely had a hand in the 1770 painting. Through a close comparison of the 1770 and 1773 images, Nantes-museum-curator Bernard Guillet contends that the two were not the work of L'Hermite alone. Guillet hypothesizes that Jean-Baptist FautrelGaugy, the Marie-Séraphique's captain, was probably the second artist. Fautrel-Gaugy was, like L'Hermite, a veteran officer, having captained slave ships since 1765/6, a position he would have earned by serving as an officer on numerous other slavers. Tellingly, Fautrel-Gaugy was the scion of a family of accomplished Nantes artists, from whom he would have perhaps inherited the skills to capture the impressive detail and perspective that is evident in both the 1770 and 1773 images of the Marie-Séraphique. Fautrel-Gaugy and L'Hermite could have spent their spare time aboard the vessel working on the paintings together; alternatively, they may have rendered them after the conclusion of the voyage. Regardless, the two men's work shows a level of skill that far exceeded that of the abolitionist draftsman who executed the Brooks diagram. Moreover, both men were well-acquainted with the way that enslaved people were transported on the Marie-Séraphique-a vessel that Fautrel-Gaugy and L'Hermite each spent 1,716 days aboard between 1769 and $1775 .{ }^{11}$

people carried by British slave ships, see, http://slavevoyages.org/voyages/ORscp1uo; and for French ships, see, http://slavevoyages.org/voyages/XLg0gTt9.

${ }^{11}$ L'Hermite served as first lieutenant on the Marie-Séraphique in 1773/74 voyage (ID 31003), and then as second captain of the Roi Negre in 1776/77 (ID 31059), again with Fautrel-Gaugy. He officered non-slaving vessels during the American Revolutionary War before his promotion to captain of the Prince Noir in 1783 (ID 31108). After 1785, he disappears from the historical record. For L'Hermite, see, Guillet, Marie-Séraphique,11-12. Fautrel-Gaugy's first command was aboard the Roi Guinguin (ID 30789) in 1764. For Fautrel-Gaugy, see, Ibid., 12, 45. The time that the two men spent aboard the Marie-Séraphique is based on the voyage lengths in the TSTD. Why Fautrel-Gaugy and L'Hermite decided to draw the Marie- Séraphique instead of the other vessels that they both served upon is unclear. 
Fautrel-Gaugy's and L'Hermite's 1770 image of the Marie-Séraphique's slave deck contains all the features that one would expect to see on a slave ship (Figure 2). The between deck is divided into three different compartments: one for the men ahead of the mainmast, one for the boys amidships, and another, aft, for the women. This configuration of spaces, which the Brooks diagram also shows, was ubiquitous in the eighteenth-century slave trade. However, the forecastle, which appears as a space for the men in the Brooks, is sealed by a wooden wall on the MarieSeraphique and contains barrels, billets of wood, and a portion of the spritsail. This use of the forecastle for storage was common. The base of the capstan runs across the middle of the men's room, forming an awkward wooden barrier across which some male slaves are slumped. The wooden walls within the room, demarcated by black and white checkered lines in the painting, do not run in clean perpendicular lines as in the Brooks, and instead form two boxed-in spaces around hatches leading below deck—barriers that prevented the male slaves from breaking into the hold. The intervening space between the men's and women's room, which appears as a wide space filled with enslaved boys in the Brooks diagram is, in the Marie-Séraphique image, a mere five or six feet wide. The room is so narrow because sails, ropes, and tools occupy their own space, closed off by bare walls on the men's side, and walls with doors on the women's side. Platforms jut from the side of the women's room but do not run to the aft of the vessel because of the cabinets and lockers located there; the men's room features no platforms at all. The Marie-Séraphique appears as a functioning sailing vessel converted into a floating prison through modification to the cluttered between deck space — a contrast to the empty spaces shown in the Brooks diagram. ${ }^{12}$

\footnotetext{
Perhaps Gruel commissioned the works to commemorate the ending of the voyages of his most valuable slaver, which had sentimental value because it carried his wife's name. Both works include tables that Gruel could have looked fondly on to recall past successes in the trade. As a former resident of Saint Domingue, Gruel might also have kept the 1773 painting as a reminder of his former home. Regardless, Gruel appears to have kept the images of the MarieSéraphique as a memento of his investment in a business that he clearly viewed as morally legitimate.

${ }^{12}$ For slaves breaking into the hold through the hatchways, see, Testimony of Ecroyde Claxton in Lambert ed., HCSP, LXXXII, 36; Testimony of James Arnold in Lambert ed., HCSP, LXIX, 133.
} 
The Marie-Séraphique diagram accurately captures the complexities of a slave ship's between-deck, which crewmen adjusted to accommodate the varying proportions of men, women and children that they expected to purchase at particular African markets. Parry's report reveals, for example, that Liverpool merchants adjusted the rooms and platforms to accommodate greater or smaller numbers of men or women depending on their vessel's destination in Africa. For example, one of the vessels from the Windward Coast, where captains bought significant numbers of enslaved males, had platforms in the men's and boys' room, but not in the women's room. By contrast, one of the vessels returning from the Bight of Biafra, where captains expected to purchase large numbers of females, had platforms only in the women's room. The Marie-Séraphique's outfitters may have adapted her to imprison more women, but more likely the lack of platforms in the men's room was due to the low ceiling in that space, which made it difficult to fit platforms. Liverpool captain Robert Norris told Parliament, for example, that "it is sometimes is the Case [sic], that there is only a Platform in the Women's Room" because a "Break in the Deck" made the "Men's Room lower, and no Platform." The configuration described by Norris is clear in the 1893 image of the Marie-Séraphique, which shows the women's room as having a higher ceiling than the men's room. Moreover, the cluttered aft section of the women's rooms, as shown in the Marie-Séraphique image, likely prevented the construction of platforms, another commonality with other slavers. ${ }^{13}$

The Marie-Séraphique's two officers executed the appearance of their African prisoners in remarkable detail. The men slaves appear, as they would have been on the vessel, completely

\footnotetext{
${ }^{13}$ For Parry's measurements, see, Lambert ed., HCSP, LXVII, 6. Parry noted that three others vessels that he had not measured precisely were "fitted in the same manner" as the ships from the Windward Coast and Biafra, implying that the addition or removal of platforms from particular rooms was a common practice. For vessels without platforms or with platforms only in certain rooms, see also, Testimony of John Matthews in Lambert ed., HCSP, LXVIII, 19; Testimony of William Littleton in Ibid., LXVIII, 224; Testimony of James Towne in Ibid., LXXXII, 19. Testimony of Robert Norris in Ibid., LXVIII, 17.
} 
naked, their right leg joined to the left leg of another man by a bar like shackle. The women, by contrast, wear blue loincloths and are unshackled. Most of the captives lie in parallel rows, as they do in the Brooks diagram, because, as numerous witnesses described, whip-bearing crewmen led the Africans below deck in long lines from the main deck every night and then forced them into position. The captives are depicted occupying just 6'3" square per person, within an inch of the average degree of crowding of Liverpool voyages between 1782 and 1788 (median: 6'4”). Unlike the supine rows of slaves in the Brooks image, the captives on the Marie-Séraphique are pressed on their sides against their neighbors_- "locked spoonways" as the Brooks' surgeon described before Parliament. Moreover, individual captives are packed into the small spaces where the rows of slaves could not fit, such as around the capstan, the edges of walls, and even atop ledges. Almost every captive lies on their right side, something that the crew "considered," according to one nineteenth century slave ship sailor, "preferable for the action of the heart." The slaves' right arms are pinioned beneath those of their neighbor; they use their left arms as a pillow, stretch it above their head, or rest it across their chests. While the captives are in rows, they still appear as people in a crowded prison, with legs, arms, and heads tangled together; bodies stretched uncomfortably across wooden beams; and others pushed into corners. ${ }^{14}$

\footnotetext{
${ }^{14}$ We have calculated the deck area for the slaves aboard the Marie-Seraphique by taking the horizontal area of her rooms $\left(1,636^{\prime}\right)$ and adjusting for the platforms in the women's room, which measure 23' by 6' on either side of the room. The platforms increases the deck area by 276', giving a total area of 1,911'11'. For images of slaves above deck on eighteenth century vessels during the day, see the 1788 image of the Danish ship Friedensborg II. Both slave ship logbooks and numerous slave traders who appeared before Parliament likewise confirmed that enslaved Africans were on deck during the day. Naturalist Henry Smeathman, who visited a British slave ship in the 1770s, gives the best description of how enslaved people were then sent below at the end of the day. The male slaves were, he wrote, "taken off by ones and two's," the officers examined the shackles of each pair of men and then sent them through the hatch below. "One couple examined and gone down, another is taken off," he added. See, Deirdre Coleman ed., Henry Smeathman, "Oeconomy of a Slave Ship," in Brycchan Carey and Peter J. Kitson, eds., Slavery and the Cultures of Abolition: Essays Marking the Bicentennial of the British Abolition Act of 1807 (Rochester, NY, 2007), 146. Once below, a "white man sent down among the men," a former slave ship captain wrote, "la[id] them" in "rows to the greatest advantage" (John Newton, Thoughts on the African Slave Trade (London, 1788), 34). A former mate on a slaver task told Parliament that he "adjust[ed] their arms and legs, and prescribe[ed] a fixed place for each." (Testimony of William James in Lambert ed., HCSP, LXIX, 137). Testimony of Thomas Trotter in Ibid., LXXIII, 834 (“locked”). Brantz Mayer, Captain Canot; Twenty Years of an African Slaver (New York, 1854), 71 ("preferable”).
} 
The depiction of individual slaves brings them to life compared to the captives depicted in the schematic Brooks image. Unlike the ranks of clones in the Brooks picture, the slaves in the Marie-Séraphique differ in height, build, and appearance. In the men's room, tall male captives are overwhelmingly around the widest sides of the vessel, while small teenagers and boys are pressed into smaller intervening spaces, likely because the crewmen assigned captives places based on their height. The women sleep atop cabinets, shelves, and narrow ledges, and their heads and bodies emerge from the bottom of the platforms in a disorderly fashion. Some women are wearing beads around their ankles, and others have changed their loin cloth into a long cloth wrap that runs from their navel to their knees. One woman, who wears a long piece of cloth as a skirt, nurses a baby at her breast - a common occurrence in a trade where Europeans purchased mothers and their infants, and even pregnant women who gave birth aboard. Another woman rests on a narrow ledge above the nursing woman's head, a small child at her feet—perhaps her daughter; a neighbor hangs her legs over the same ledge. Seven captives are wrapped in blue cloths and lie in agony on the walled-in hatchways - the sickly captives whom the crew tried to quarantine from their shipmates. ${ }^{15}$

The memory of being packed "spoonways" into the fetid holds of slave ships is so powerful that it has even been incorporated into a Haitian Voudon ceremony today. During the first stage of initiation, anthropologist Katherine Dunham described how she and eight others were "lying on a dirt floor spoon fashion, well fitted into each other." A priestess then entered the room and ordered the initiates to "rise up and turn," just as the crewmen on a slave ship would have. "We sat and turned to the other side, as we had done every few hours since our confinement." Dunham's neighbor also urinated on her. "There we lay, scarcely breathing, waiting, listening, senses alert," she wrote, "packed like sardines much as the slaves who crossed the Atlantic, motionless as though chained, some of us afraid" See, Andrew Apter and Lauren Derby eds., Activating the Past: History and Memory in the Black Atlantic World (NEwcastle, 2010), xv-xvi.

${ }^{15}$ Canot states that when he personally packed captives "attention is paid to size, the taller being selected for the greatest breadth of the vessel, while the shorter and younger are lodged near the bows" (Ibid). For the wearing of cloth and beads by enslaved women and children, see, December 17, 1771, Henry Smeathman's Journal Book, Uppsala University Library. For the use of walled-off sick bays, see, Lambert ed., HCSP, LXIX, 35; Testimony of Robert Norris in Lambert ed., HCSP, LXVIII, 5; Testimony of Archibald Dalzell in Ibid., LXIX, 121. For the covering of sickly slaves with cloth, see, Testimony of Ecroyde Claxton in Ibid., LXXXII, 33. 
The accompanying depictions of the Marie-Séraphique's above decks, hold, and the view of her at anchor in Africa, include important additional details that shed further light on the slaves' experiences, and especially the crew's concerted efforts to prevent insurrections (Figures $2 \& 3$ ). Ranks of wooden water barrels fill the hold, each fixed in place by billets of wood that would be used to cook the slaves' twice daily meals in a boiler aft of the mainmast - the beans, rice, manioc flour, and bread being depicted in storage compartments in the aft of the hold. Imprisoned in the Marie-Séraphique's between decks throughout the night, the captives would have heard the water sloshing in the barrels below, and rats scurrying amongst the food and water. In fair weather, the crewmen would have brought the captives up in the morning through thick-iron-grated hatchways - one of which is shown open in the diagram of the above-deck-onto the main deck. The above deck was not, as one of the cross-sections accompanying the Brooks image shows, an empty space, but rather an area cluttered with water barrels, food, trade goods, caged livestock, and the winches and pulleys needed to work the ship. Iron rings along the edges of the gratings mark the places where two long "deck-chains" would have been run the length of the fore-deck. The crew would have locked enslaved men into the chain as soon as they were brought on deck, keeping them in a narrow space hemmed in by barrels to the side, and the high and wide wooden barricado shown in the 1893 image - all measures designed to forestall insurrections. While the smaller number of women would have had more room on the quarter deck and not been chained, they would have been crowded by the crew of forty-one men, almost all of whom stayed behind the barricado in case the men on the other side staged a rebellion. With 307 slaves aboard, the Marie-Séraphique's deck must have been oppressively congested, something that the artists depicted in their view of the vessel standing off Loango. The captives appear as a dense crush of 
people that must have swayed and surged with the rolling of the vessel, their heads just showing over the gunwales, shielded from the sun by two large sails. ${ }^{16}$

[Insert Figure 3 here]

The numerous images of the Marie-Séraphique thus capture the vessel and her slaves with a level of detail and complexity that far exceeds that of the simplistic Brooks diagram. The artistsboth experienced slave ship officers — served aboard the Marie-Séraphique and must have painted their prisoners from life. Their drawings show captives crushed together below deck in an accurate reflection of ship crowding. Moreover, by including images of the different levels of the vessel and a view of her at anchor, the artists convey a sense of the Marie-Séraphique as a functioning slave ship packed with hundreds of individuals. While the Marie-Séraphique diagram depicts enslaved people "supine," as Wood suggests for the Brooks, it includes myriad details that reveal the vessel as a true floating prison. ${ }^{17}$

Do the Brooks or the Marie-Seraphique depict how slave ships appeared beyond the late eighteenth century? The transatlantic slave trade had existed for 250 years before the MarieSéraphique was painted and continued under very different conditions down to the mid-1860s. We know of no surviving illustrations of slaves aboard ships before the eighteenth century; the earliest

\footnotetext{
${ }^{16}$ For provision compartments, see, Testimony of John Knox in Lambert ed., HCSP, LXVIII, 90. For rats and mice on slave ships that gnaw "through the provision and water barrels," see, Pieter Gallandat, Necessary Instructions for the Slave Traders, trans. Lieneke Timpers (Middelburg, 1769). For the bringing of slaves above deck and their imprisonment in "deck chains," see, Newton, Thoughts, 15; Coleman ed., Smeathman, "Oeconomy of a Slave Ship," 141-42. According to Smeathman, just three of the crew were before the barricado at any one time "otherwise the men slaves might seize half the crew on the sudden, and soon become masters of the vessel" (Ibid). Smeathman added that the quarter deck of the slave ship that he visited was "so crowded" with the women, children, and crew, that there was barely "room to pass." See, December 17, 1771, Henry Smeathman's Journal Book, Uppsala University Library.

${ }^{17}$ Although a more accurate depiction of shipboard conditions than the Brooks, the images of the Marie-Séraphique's 1770 voyage may not even fully capture crowding of the Africans on this vessel. On all five of the Marie-Séraphique's other voyages, the captives had less space, sometimes much less. The space per slave on the Marie-Seraphique's six voyages was in 1765/66: 5' square per person (ID 30806); 1769/70: 6’3" (ID 30910); 1770/71: 6" (ID 90941); 1772/73: 5'7' (ID 30968); 1773/74: 5'2” (ID 31003); and 1776/77: 4'6”' (ID 31051).
} 
is a crude painting from a church in the aftermath of the ship's apparently miraculous escape from wrecking on a shoal in 1743. But the very earliest transatlantic captives must have travelled under conditions that their successors could not have imagined. David Wheat and Marc Eagle have recently collected data on almost a hundred ships arriving in Puerto Rico direct from Africa between 1520 and 1540. On average, they carried just sixteen slaves. Such ships would have been galleons or carracks with high forecastles and the mix of square and lateen sails not markedly different from the vessels that allowed the Portuguese to enter the Pacific and Indian Oceans. They would have set out from the Iberian Peninsula carrying European merchandise and Spanish migrants before picking up slaves—all originally from Upper Guinea—in the Canary Islands. With crews and immigrants greatly outnumbering captives, men slaves might have travelled in conditions not radically different from free migrants, barring their shackles. ${ }^{18}$

By the mid-1560s the average number of slaves embarked began to match those on the Marie-Seraphique and Brooks, but this was nevertheless a much different trade. The original Atlantic slave traders, mainly Portuguese, created and maintained a system that saw slaves accumulated and partially housed on shore prior to embarkation in fortified locations-Philip Curtin called them "bulking centers". Vessels could spend a year or more on the African coast but were frequently empty during this time or had few slaves on board. Embarkation, or, at least, embarkation of a ship's full "complement" was delayed until just prior to departure. On islands and in coastal settlements, the Portuguese created a secure environment in which to trade and hold captives for extended periods of time. No other European power was able to achieve such security

\footnotetext{
${ }^{18}$ The 1743 painting is the frontispiece in Para Nunca Esquecer: Negras Memórias, Memórias de Negros (Rio de Janeiro, 2001). In the 1550s detailed records of two large transatlantic vessels suggest that each disembarked over one hundred slaves in Hispaniola and Vera Cruz respectively. But on arrival they were also found to be carrying huge volumes of wine, olive oil, and a wide range of manufactured goods (Marc Eagle and David Wheat, "The Early Iberian Slave Trade to the Spanish Caribbean, 1500-1580," in Alex Borucki, David Eltis and David Wheat (eds.), From the Galleons to the Highlands: Slave Trade Routes in the Spanish Americas (forthcoming University of New Mexico Press)). We thank the authors for giving us access to these data prior to their publication.
} 
outside the walls of the forts that they erected - mostly located on the Gold Coast. For the extensive French, Dutch and English slave trades in the Bights and north of the Congo River, by contrast, the vessel was the trading platform and its captain interacted directly with African suppliers. No shipboard trade at a single African embarkation point matched the 2.8 million slaves that left from Luanda - the hub of the Portuguese slave trade. This Portuguese advantage is one of the largely unexplored factors explaining why Portuguese/Brazilians were the dominant EuroAmericans involved in the slave trade in every era of the slave trade except for the last half of the eighteenth century. ${ }^{19}$

The Portuguese system, as we might label the system of bulking and then shipping slaves, had two major implications for the experiences of captives on the Atlantic crossing. First, they spent less time on board a slave ship, and second, the share of that time spent at sea was also less. A French, British and Dutch slaver between 1640 and 1807 typically received its first captive eighty days after leaving home port. Accumulating a full complement of captives took a further 140 days, while the transatlantic passage added seventy-three days more, with a further week often elapsing prior to sale of the captives in the Americas. The very first captive purchased would hence enter an almost empty vessel, where they spent a mean of seven months. Ships then became increasingly crowded as the captain continued to purchase enslaved people over a several-month period; severe crowding below decks usually began two or three weeks before departure when the

\footnotetext{
${ }^{19}$ Jean Cuvelier (ed.), Relations sur le Congo du Père Laurent de Lucques, 1700-1717 (Brussels, 1953), 13 ${ }^{\text {th }}$ Relation of the Capuchin Friar, Father Laurent de Lucques, Bahia, August 27, 1708. See also the 1667 voyage on the same route described by Michael Angelo of Gattina and Denis Carli of Piacenza, where six hundred slaves were loaded when the ship was ready to sail (Awnsham Chuchill and John Churchill, Collection of Voyages and Travels: Some Now First Printed from Original (London, 1704), I, 637). See also Miller, Way of Death: Merchant Capitalism and the Angolan Slave Trade, 1730-1830 (Madison, WI, 1986), 405-406. For the Senhora do Cabo, see ID 40839. Linda Newson and Sue Minchin, From Capture to Sale: The Portuguese Slave Trade to Spanish South America in the Early Seventeenth Century (Leiden, 2007), 72-100. Francesco Carletti, writes of seventy-five slaves that he accompanied to Cartagena being placed on the ship in Santiago, Cape Verde Islands in 1594 just prior to departure (My Voyage Around the World, trans. Herbert Weinstock (London, 1965), 15).
} 
captain began to pay higher prices for slaves to get off the coast as quickly as possible. We lack precise data for Portuguese vessels given that time of arrival on the African coast does not correlate well with their date of first embarkation of a slave. But, in the light of the above evidence, captives would likely board a vessel together and immediately be crushed together. The second implication between these different methods of shipping is the amount of time that captives spent at sea. Portuguese and Brazilian slave ships supplied the part of the Americas that was closest to Africa. Their British, French, and Dutch counterparts faced voyages that were fifty percent longer in reaching their major markets in the Caribbean than the Portuguese experienced in sailing to Brazil—in every quarter century between 1676 and 1807. Africans would consequently endure ship crowding aboard Portuguese flagged vessels for less than two months. Their counterparts in the British and French trades endured both longer periods aboard vessels off the African coast, where they became increasingly crowded as the ship filled with prisoners, and then much longer voyages on those packed vessels across the Atlantic. ${ }^{20}$

How different was the slave experience aboard these Portuguese vessels to that shown in the Brooks and Marie-Serpaphique diagrams? Alonso do Sandoval collected information from hundreds of Africans in early seventeenth century Cartagena and wrote what is probably the best ethnological treatise on early modern Africa, including a description of the conditions aboard the slave ships. According to Sandoval, slaves were chained together and "locked in the hold and closed off from both the sun and the moon" where they lay "with one person's head at another person's feet." Scholars have taken this to mean that adult males were held below deck throughout the voyage, which an abundance of evidence makes clear was not the case in the eighteenth

\footnotetext{
${ }^{20}$ For increases in slave prices prior to the departure of ships see Nicholas Radburn, forthcoming. The duration of the different phases of the voyages are calculated from TSTD. There are many instances in the TSTD where captives spent a year aboard the slave vessel between embarkation and disembarkation. See, http://slavevoyages.org/voyages/FdFBrwz5, tables tab for middle passage times by broad region of disembarkation.
} 
century. We know that a key feature on eighteenth-century slave ships was a barricado at midships_-something that appears in both the Brooks and the Marie-Séraphique images. Remarkably, historians have not interrogated when slave traders began to employ the barricado, but we have found no evidence of its use in the Portuguese trade, nor in the pre-1700 slave trades of other nations. The Brooks, and indeed the Marie-Séraphique, images are thus of limited use in depicting the African experience of the Portuguese slave trade, and perhaps the experiences of captives on British or French vessels sailing before the eighteenth century. ${ }^{21}$

The illegal phase of the trade after 1807 introduced even more variety into shipping practices in the slave trade. As British naval patrols gradually extended their blockade of the African coast, the strategy of holding slaves on land prior to embarkation-the Portuguese system - became the only feasible method of shipping slaves. By this time, however, it was a device for avoiding the attentions of British naval vessels that, until the inclusion of "equipment clauses" in anti-slave-trade treaties in the 1830s, could detain a slave ship only if it had captives on board. Moreover, both improved ship design and British deployment of its anti-slave trade squadron meant that slave traders began to employ faster vessels to outrun naval cruisers; they also saw the benefit of transporting what they saw as high-value "perishable" human cargoes as quickly as possible. Rapid development of both sailing and steam ship technology culminated in the employment of yacht- or clipper-type and, later, steam-powered vessels. Just as today, the ratio of sail to hull, and the shape of the hull determined speed. Compared to the Marie-Séraphique and

\footnotetext{
${ }^{21}$ Alonso de Sandoval, Treatise on Slavery Selections from De instauranda aethiopum salute, ed. and trans. Nicole von Germeten (Indianapolis, IN, 2008), 56-57. Such an interpretation is not supported by the original text. This was the NS de Nazaré e S Antônio (ID 8148).
} 
the Brooks, slave ship hulls from the 1810s onwards had a straighter profile, fewer decks, a sharper entry into the water, along with raked masts that supported a greater sail area. ${ }^{22}$

These myriad changes in shipping practices during the illegal era, both to maximize profits and avoid naval interdiction, introduced enormous variety in the ways that captives were transported, and consequently those captives' experiences. For example, between 1816 and 1850 ten open launches are known to have carried off slaves from Africa, all steering for Brazil and most confirmed as arriving successfully—a radically different experience to the millions of captives who were shipped on multi-decked sail-ships such as the Brooks. Slave traders also packed captives in the illegal era into remarkably small spaces that fundamentally altered the African experience of the Atlantic crossing. In 1842, a 29-ton vessel bound from Ambriz to Brazil took off 127 captives - over half of them children. The height between water casks and the underside of the deck was just one foot two inches, and "one half of the slaves were obliged always to be on deck where they were so confined that every foot of the deck was occupied, while the reminder below were squeezed to excess." On the Aerostatico, a Spanish-flagged vessel destined for Cuba in 1829, 108 "boys and girls" were likewise packed into a hold just twenty-two inches high. The person who forced the captives into the hold described them as like "sardines in a can." By contrast, the Orion (ID 4807) had, according to the arresting officer in 1857, "the finest slave deck I have ever seen being about 8 feet in height and clear fore and aft.” In addition, blockades by the British squadron had forced it to leave the coast with only two-thirds of its intended captives on board. Two years later the Manuela (ID 46907) had seven feet headspace on the slave deck

\footnotetext{
${ }^{22}$ For an assessment of improved sailing ship performance in this era, see Morgan Kelly and Cormac Ó Gráda, "Speed under Sail, 1750-1850," (Unpublished paper, 2014 available at http://www.ucd.ie/t4cms/WP14_10.pdf). For changes in techniques for shipping slaves during the illegal era, see also, Thomas, The Slave Trade, 561-785. Changes in slave ship design are particularly visible in images of naval cruisers interdicting captured vessels. See, for example, http://slavevoyages.org/resources/images/category/Vessels
} 
when detained, which was also "well-ventilated." Both the Orion and Manuela were clipper-type ships in 600-700 ton range, no doubt hurriedly converted from cargo to slave use; one had been intended for the China trade. Then there were the twenty-three steam-powered slave ships in the voyages database averaging 361 tons and disembarking on average 1,004 captives - truly slave trading in the industrial era. ${ }^{23}$

While it would be impossible to visually capture this variety in shipping practices, analyzing three images does give some sense of differences to the conditions shown in the Brooks and Marie-Seraphique images. The ironically named Legítimo Africano, detained in 1835, was a small vessel, fifty tons, without cannon and built for speed (Figure 4). Yet, it carried 190 people in an area of four hundred square feet and with a deck height of just 1' ${ }^{\prime \prime}$. As the scale drawing shows, the owners had abandoned any semblance of a slave deck as well as all partitions between decks. Instead, the crew formed a makeshift platform by filling the spaces between the casks with bags of provisions. The key element that made this possible was that all but one of the 190 Africans were children. Scholars have addressed the issue of children in the slave trade by focusing on shifting cultural patterns within Africa, especially the large regional and ethnic variations in child ratio. However, the jump in the proportion of children carried from all regions in the nineteenth century indicates that slave traders may have embarked increasing numbers of children to reduce

\footnotetext{
${ }^{23}$ For the ten open boats, see http://slavevoyages.org/voyages/sse2CNIZ. The most spectacular case set out from Freetown, the command center of British efforts to suppress the traffic. Five sailors from a recently condemned slave ship stole a boat belonging to the Mixed Commission Court and, as the British Commissary judge related, "pulled up to the Rio Pongo where they either kidnapped or purchased five or six slaves, with whom in an open Boat about 28 or 30 feet long they started for Brazil and arrived there in safety." See, James Hook, Sierra Leone, to Lord Palmerston, November 11, 1849, BNA, FO84/752.For the unnamed 29-ton vessel, see Admiralty to Lord Aberdeen, Sept. 15, 1842 (enc.) BNA, FO84/441. For the Aerostatico (ID 772), see, Mayer, Captain Canot, 50. For the Orion, see, Admiralty to Lord John Russell, March 13, 1860, enc. Lt. Simpson to Capt. Courtenay, Dec 1, 1859, BNA, FO84/1123. For the Manuela, see, Michael R. Bouquet, "The Capture of the 'Sunny South' Slaver," History Today, 10 (1960): 573-78. The average height of the slave deck for twenty vessels, including all the cases mentioned here was 3 feet 7 inches (data available from the authors), though the sample is not random given that observers were more likely to record extreme cases, most of which would have been at the low end.
} 
security costs through the elimination of barriers, platforms, and chain along the decks - all features that were emblematic of the eighteenth-century slave trade. The British found an identical below-deck configuration on the 45-ton Jesus Maria, for example, with 246 surviving Africans on board of whom only five were adults - all, unsurprisingly, women. Crossing the Atlantic without a fixed slave deck became more common after the 1835 Anglo-Spanish treaty permitted seizure of vessels equipped for the slave trade, rather than having slaves on board. The treaty specifically mentioned a slave deck, or the presence of materials to make the same, as grounds for detention. Naval officers reported at least a dozen cases of vessels missing slave decks after 1835, describing sand ballast or firewood filling the spaces between casks, or sometimes simply "hides laid on the tops of leaguers," though such a practice never became the norm. ${ }^{24}$

\section{[Insert Figure 4 Here]}

The painting of the slave hold of the Albanez (ID 3483) shortly after its interdiction in the Congo River in 1845 captures how Africans may have been transported in vessels lacking a fixed slave deck (Figure 5). The painter, Francis Meynell, is probably sitting on the forward stairs looking aft and Africans can be seen on the casks. Frequently reproduced, the image is certainly authentic and, in this respect, it matches the drawing of the Marie-Séraphique. The painting is not intended as a depiction of conditions on the Middle Passage because the apprehending cruiser,

\footnotetext{
${ }^{24}$ For the Legítimo Africano (ID 3049), see, Papers of Sir Thomas Fowell Buxton, Bodleian Library, University of Oxford, (hereafter BL), XXVII; "Report of the Case of the Portuguese schooner "Legitimo Africano," BNA, FO84/169, ff. 67-75. Except for the small and specialized traffic in children from the Gambia to Lisbon conducted on British and Portuguese ships down to the 1750s, there is no parallel to this pattern in previous centuries. See David Eltis, "Fluctuations in the Age and Sex Ratios of Slaves in the Nineteenth-Century Transatlantic Slave Traffic," Slavery and Abolition, 7 (1986): 257-72; David Eltis and Stanley, L. Engerman, "Fluctuations in Sex and Age Ratios in the Transatlantic Slave Trade, 1663-1864," Economic History Review, 46 (1993): 308-23; Paul Lovejoy, "The Children of Slavery - the Transatlantic Phase," Slavery and Abolition, 7 (2006): 197-217. For the Jesus Maria (ID 2071), see, Admiralty to Palmerston, March 31, 1840 (enc.), BNA, FO84/383; J. Kennedy and C.J. Dalrymple to Lord Palmerston, Jan. 20, 1841, BNA, FO313/18. For vessels without fixed slave decks, see the sources for the following IDs: 2097, 3466, 3458, 3483, 3484, 3629, 3689, 4057, 4072, 4073, 4082, 4940. Charlotte Pilkington, Rio de Janeiro, September 23, 1840 in "Papers of the Anti-Slavery Society, 1757-1982," MSS. Brit. Emp. S. 22, G79, BL ("hides"). A "Leaguer" was a large water cask.
} 
HMS Albatross, had taken on board many of the captives prior to the long voyage to adjudication in Freetown. Thus, the viewer sees the real below-decks of a slaver, but only some of the captives. Even so, the image evocatively captures the chaos of a dimly lit slave deck. Africans are spread uncomfortably across the tops of barrels, some on mats, some on the bare wooden hoops; one captive sits on a latrine in the foreground, wrapping himself with his arms. Above the barrels, slaves perch and lie on wooden beams, some with their legs dangling over the ledge. Many more captives are crammed together on platforms running along the vessel's side, one of the only commonalities with the Brooks and Marie-Seraphique. Light pours in from the ceiling but only illuminates the captives in the center of the image. The fact that it is daylight gives some sense of how the Africans would have experienced the Middle Passage: packed below deck on whatever few inches of space they could find. ${ }^{25}$

[Insert Figure 5 Here]

While the Albanez and Legítimo Africano give some sense of the holds of illegal slavers, the recently unearthed painting of the Diligente (Figure 6) reveals the sheer mass of humanity that slave trader crammed onto their vessels. The Diligente (ID 2588) was a 174-ton brig depicted leaning in slightly toward the painter. It carried 475 Africans-survivors of 520 embarked at Lagos. Detained on its way to Cuba in 1838 , the Diligente provides, at first glance, the most accurate depiction of the fair-weather day-time experience of captives for any period; not even the image of the Marie-Seraphique (Figure 3) provide such a view. But things are not quite what they seem. The deck shows fewer than half the number of captives that we can document as disembarking a few days after the detention. Furthermore, the seven blue-jacketed figures can only be the prize crew from HMS Pearl, not the original slave ship crew. Thus, the artist is probably on

${ }^{25}$ Francis Meynell, 1845, "Rescued Africans on deck of HM Sloop 'Albatross'," National Maritime Museum, Greenwich, UK, D9316. 
the quarter-deck of HMS Pearl as the naval vessel conducts its prize to Nassau in the Bahamasthe capture having taken place in the Caribbean, not off the African coast. The missing two hundred or so Africans are either below decks or, more likely, on board the naval vessel to relieve crowding. But here, as with all the other Portuguese vessels mentioned here, there is no sign of a barricado. There is no illustration of, nor indeed any documentary reference to, such a structure in the illegal era, something that makes sense given the need to conceal the vessel's intentions from the British Navy. Crewmen likely enforced the separation of male and female slaves through restraints and violence or, alternatively, kept captives below deck for the voyage. To derive a perspective of precapture conditions on the Diligente we thus need to imagine double the number of figures depicted in the painting, crammed below deck.

\section{[Insert Figure 6 Here]}

Three illustrations cannot encapsulate the experience of captives in the nineteenth century slave trade, but they can indicate changes in that experience over time. The illegal phase of the trade as represented in the voluminous reports of British naval officers communicates a sense of the wild west where, especially after the 1835 equipment clause, almost anything was possible. Such variation in shipping practices does not permit easy distillation of the average experience, but it does allow us to discredit the Brooks image as emblematic beyond its own time period. And it suggests that major differences existed between the Northern European and the Portuguese systems both before and after 1807 that are not recognized in either the Brooks or the MarieSéraphique images.

\section{*}

For over two-hundred years the image of the slave ship Brooks has evoked, as Clarkson observed, "an instantaneous impression of horror upon all who saw it." The poster showed 470 
Africans crammed into spaces in which they could do nothing but lie on their backs, a degree of crowding equivalent to 7'2" square per person. Prior to the passage of regulatory acts in 1788 , perhaps a fifth of Africans were transported in such conditions on British slave ships. The majority of captives were carried across the Atlantic squeezed into spaces measuring, on average, just 6'4" square - the kind of conditions depicted in the images of the Marie-Séraphique. These Africans were not arrayed in neat rows, shoulder to shoulder, in a clean hold, as the Brooks shows. Rather, they were pressed together into each other's arms, and unable to move, hemmed in by barrels, ropes, spare sails, walls, and low-ceilings. Remarkably, these already wretched conditions may have deteriorated further in the nineteenth century as slave traders sought to escape naval interdiction through the employment of vessels that sacrificed space for speed. Contemporary images reveal these important changes, with captives perched atop barrels in a slaver's hold, or pressed together on a thronged top-deck. Our analysis of the Brooks alongside numerous alternative images thus suggests that the African experience of the Middle Passage was worse than the "horror" depicted in the diagram, and that those horrors may have increased in the trade's illegal era. ${ }^{26}$

But our analysis is also revealing of the limitations of using flat, schematic contemporary images to visualize the Middle Passage. While the image of the Marie-Séraphique is remarkably detailed it suffers from many of the same flaws as the Brooks diagram and other contemporary images of slave ships. Two-dimensional and diagrammatic representations of slave ships will not get us closer to the African experience even if the accompanying text is written with passion and feeling, as much recent work on the Middle Passage has been. Moreover, flat images of a single vessel in one period fail to capture the complexity of a trade that changed enormously over its

\footnotetext{
${ }^{26}$ Clarkson, History, II, 90.
} 
several-hundred-year history. Historians consequently need to think of new ways of visually depicting the Middle Passage. Ship-modeler Jean Boudriot demonstrated one such approach in his 1984 work on the French slave ship L'Aurore (ID 32359), which sailed from Angola to Saint Domingue in 1784. Boudriot reconstructed L'Aurore in incredible detail, including all the equipment that one would expect to find on a slave ship. Importantly, Boudriot also sketched the Aurore's six hundred captives between decks, providing a vivid diagram of a fully loaded slave ship that was not marred by the biases of either slave traders or abolitionists. A team at Emory University is currently digitally rendering Aurore using Boudriot's blueprints, with his sketches of the captives overlaid as transparencies to provide a sense of the crowding on the Middle Passage. The Dutch National Archives have also produced a digital model of the slave ship Unity, which conducted several voyages in the 1760s. Although the three-dimensional model does not include renderings of slaves, it still has a physicality that gives the viewer a sense of the Unity as a functioning slave ship. The Aurore and Unity projects both overcome many of the limitations of diagramatic contemporary images because they allow historians to select representative vessels from different eras. Advances in digital technology may thus enable us to finally "make the slave ship real. ${ }^{27}$

\footnotetext{
${ }^{27}$ For recent works that seek to describe the "human history" of the slave trade, see, Rediker, The Slave Ship, 308 ("make"); Stephanie E. Smallwood, Saltwater Slavery: A Middle Passage from Africa to American Diaspora (Cambridge, MA, 2007); Sowande M. Mustakeen, Slavery at Sea: Terror, Sex, and Sickness in the Middle Passage (Urbana, IL, 2016). Jean Bourdiot, Traite et Navire Negrier (Paris, 1984). We are thankful to the Emory Center for Digital Scholarship for providing access to their prototype model of L'Aurore. "MCC Slave Voyage The Unity, 17611763," Zeeland Archives, https://eenigheid.slavenhandelmcc.nl/slaves-journey/?lang=en
} 


\section{$\underline{\text { Appendix } 1}$}

The Liverpool ship registers include the length and breadth of slavers, and the height between decks. When the surveyor measured the slave ship Bess in 1789, for example, it was 68'6" long, 21'10" wide, and was 4'5" high between decks. Multiplying the length of the vessel by its breadth gives the rectangular surface area of the ship's deck, in the case of the Bess, 1,495' square. Dividing the area of the deck by the number of captives embarked according to the TSTD gives the area in square feet per person-that is the level of crowding. The 206 enslaved Africans forcibly embarked on the Bess at New Calabar in 1789 thus had 7'2" square per person using that measure. But the Liverpool surveyors did not take the exact dimensions of the slaves' rooms, which typically included platforms that increased the amount of space in which the Africans had to sleep. Neither was the entire length and breadth of the ship occupied by rooms for the slaves, because the vessel often had storage room at the aft of the ship. Moreover, a ship was not a perfect rectangle, because it bulged amid-ships, narrowed to a point at the bow, and was wider below decks than above. We have thus adjusted the rectangular surface area of the decks obtained from the register by using a constant derived from Parry's report—providing the area actually occupied by the slaves. Parry measured the length and breadth of the individual slaves' "rooms," and the "platforms" that slave traders built into the side of the rooms. By only measuring the areas where the slaves were imprisoned, Parry's figures also did not include storerooms and cabins used by the crew. Parry's report shows that the total space for slaves was, on average, sixteen percent larger than the deck-area per the Liverpool register. In the case of the Bess, then, the area for the slaves increases from 1,495 ' square, to 1,734 ' square, giving each captive an average of 8'5" square $\left(1,734^{\prime} / 206\right) .^{28}$

\footnotetext{
${ }^{28}$ For the use of Parry's measurements by Parliament to assess ship crowding, see, Lambert ed., HCSP, LXVIII, 4243.
} 